
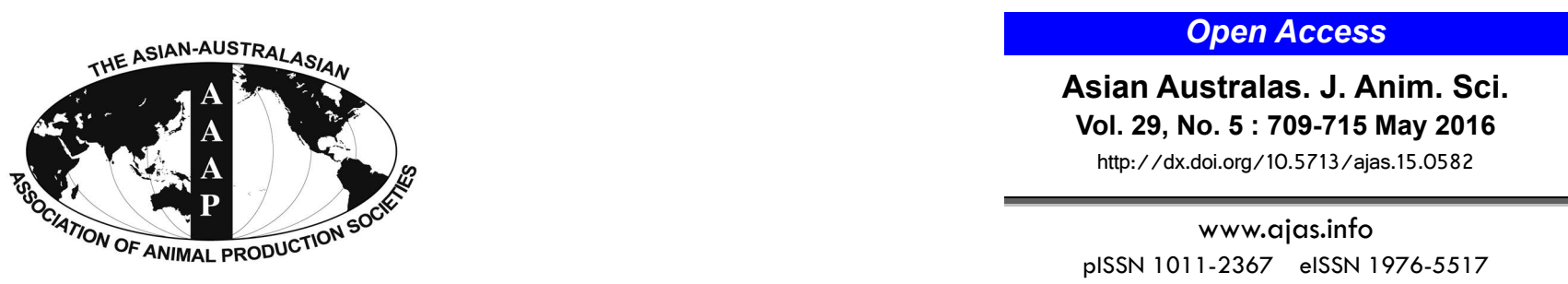

\title{
Quality Characteristics and Composition of the Longissimus Muscle from Entire and Castrate Elk in Korea
}

\author{
Sang-Woo Kim, Kwan-Woo Kim, Seong-Bok Park, Myung-Jick Kim, and Dong-Gyun Yim ${ }^{1, *}$ \\ Animal Genetic Resources Center, National Institute of Animal Science, RDA, Namwon 590-830, Korea
}

\begin{abstract}
The objective of the research was to determine the chemical composition as well as the physicochemical properties of the longissimus muscle from Korean entire and castrate elk. Twelve elk stags were raised and fed on concentrate with ad libitum hay. All animals were equally divided into castrated and non-castrated (entire) males, and slaughtered at 5 year of age. It was found that entire elk, in comparison with castrate elk, had higher content of moisture and lower content of fat $(p<0.05)$. Compared with entire males, the castrates had lower $\mathrm{pH}$ and shear force values $(\mathrm{p}<0.05)$. However, castrates had higher $\mathrm{L}^{*}, \mathrm{a}^{*}$, and $\mathrm{b}^{*}$ values compared with entires $(p<0.05)$. An analysis of the fatty acid profile revealed that the muscles of entire and castrate elk had the most abundant concentrations of the following fatty acids: palmitic acid (C16:0) of the saturated fatty acid, and oleic acid (C18:1n-9) of the unsaturated fatty acid. The entire elk contains higher proportions of linoleic acid (C18:3n6), eicosenoic acid (C20:1n9), and arachidonic acid (C20:4n6) ( $<<0.05)$. Cholesterol content in elk was not affected by castration. The predominant free amino acid was glutamic acid related to umami taste. It is apparent that the castrate animals carried higher content of histidine, isoleucine, and leucine than those of the entire group ( $p<0.05$ ). In this study, it was concluded that venison quality of elk is affected by castration and these results can provide fundamental information for venison production. (Key Words: Elk, Castration, Meat Quality, Fatty Acid Composition, Amino Acid Composition)
\end{abstract}

\section{INTRODUCTION}

The primary products produced from deer are venison and velvet antler. Velvet antlers are soft growing bony organs which are cast and fully regenerate every year $(\mathrm{Li}$, 2003). It is mostly consumed in Asian countries including Korea as an ingredient of traditional oriental medicine (Miao et al., 2001). The product of velvet antler, and other minor by-products are all valuable but in the long term, venison product is likely to be the most crucial characteristic (Drew, 1991). Venison is seen as a high-value meat owing to the high content of protein and minerals, as well as low fat and cholesterol (Shin et al., 2000).

In Canada, the farmed deer population was estimated to about 162,000 animals, with 14,000 being slaughtered

\footnotetext{
* Corresponding Author: Dong-Gyun Yim. Tel: +82-55-740-1814, Fax: +82-55-743-3010, E-mail: tousa0994@naver.com

${ }^{1}$ Department of Public Health Administration and Food Hygiene, Jinju Health College, Jinju 660-757, Korea.

Submitted Jul. 8, 2015; Revised Oct. 14, 2015; Accepted Nov. 13, 2015
}

(Ministry of Agriculture, Food and Rural Affairs, 2013). In New Zealand, deer farming has developed to an important export industry. Farmers have also imported East European red deer genotypes to improve not only the antlers (for velvet production) but also the venison production (Pearse and Fung, 2007). In a recent survey it was estimated that there were about 1.1 million farmed deer in New Zealand, of which 400,000 were slaughtered in 2010 (Statistics New Zealand, 2010). In New Zealand, most common species farmed is red deer ( $85 \%$ of the total number) and more than $90 \%$ of the products (venison, velvet and co-products) were exported. In Korea, deer and elk were imported from New Zealand and North America about 50 years ago. The statistics show that 4,011 farm households have raised 48,463 head of deer and elk in Korea (Ministry of Agriculture, Food and Rural Affairs, 2013). The elk (Cervus canadensis) is one of the largest species of the Cervidae or deer family, and one of the largest land mammals in North America and eastern Asia (Pitra et al., 2004). In South Korea, elk were imported from North America between 1974 and 1976, a sub-species of the elk are crosses between 
Rocky Mountain (C. Canadensis nelsoni) and Manitoban (C. Canadensis manitobensis). Deer farming has expanded rapidly in Korea and the number of elk has increased considerably, because male elk can produce a higher amount of velvet antler than red deer (Kim et al., 2006). Nowadays, some restaurants offer venison as a healthy food in Korea, even though elk or venison is commonly harvested for meat production on a small scale. A range of objective meat quality measurements, as well as chemical and nutritional compositions of beef, pork, goat, and chicken, have been made, whilst less study on deer or elk after producing velvet antler has been undertaken.

Castration may be a useful management practice in deer or elk management systems both as a means to reduce aggressive behavioral problems associated with managing entire stags during the rut and to improve meat quality from males (Asher et al., 2011). Differences in quality and composition characteristics between the gender groups for red deer appear to have been only assessed previously (Purchas et al., 2010). There is little information on the effect of castration on the meat quality traits from elk grown in Korea. So far, a quality standard and grading system for venison are still not available in most countries. Thus, there is no well-established carcass classification system of venison in the world including Korea. Therefore, the objective of the current study was to compare a range of proximate composition, physic-chemical quality-related traits of the muscle from entire and castrate elk after producing velvet antler.

\section{MATERIALS AND METHODS}

\section{Animals feeding and castration procedure}

Twelve elk stags were raised at the Animal Genetic Resources Center, the National Institute of Animal Science (NIAS), Namwon, Korea. All experimental procedures were undertaken with the approval of the NIAS, as required by NIAS regulation under animal welfare. When the real trial was started, the average age of elks were estimated to be from 4 to $6 \mathrm{Y}$ of age. Chemical composition of experimental diets is shown in Table 1. Concentrate feed was provided twice a day in the amount of $1.8 \%$ of body weight. Hay, which is a major roughage source for deer in Korea, was offered ad libitum. Animals could drink freshwater any time from water buckets. Animals were left intact to compare the effect of castration. The age of castration was 5-year old. Castrated males were by surgical removal under general sedation and local anaesthesia. Animals to be castrated were individually sedated by intramuscular injection of $3 \mathrm{~mL} /$ head xylazine. After 2 to 3 min from injection, the scrotum was incised, the testes exteriorized and, following clamping of the cords and vessels, the testes were pulled free. A subcutaneous
Table 1. Chemical composition of experimental diets

\begin{tabular}{lcc}
\hline Chemical composition & Concentrated feed & Hay \\
\hline Moisture (\%) & 11.08 & 11.72 \\
Crude protein (\%) & 19.50 & 8.56 \\
Crude fat (\%) & 5.04 & 4.57 \\
Crude ash (\%) & 6.37 & 5.03 \\
ADF (\%) & 9.68 & 30.76 \\
NDF (\%) & 22.60 & 55.28 \\
\hline
\end{tabular}

$\mathrm{ADF}$, acid detergent fiber; NDF, neutral detergent fiber.

injection of long-acting antibiotic solution $(1 \mathrm{~mL} / 10 \mathrm{~kg}$ live weight, Norocillin LA; Norbrook NZ Ltd, Auckland, New Zealand) and an intramuscular injection of $0.5 \mathrm{mg} / \mathrm{kg}$ meloxicam, a longacting analgesic and anti-inflammatory, (2.5 mL/100 kg live weight of Metacam 20; Boehringer Ingelheim NZ Ltd, Auckland, New Zealand) were delivered prior to reversal of general sedation by intravenous injection of $0.25 \mathrm{mg} / \mathrm{kg}$ yohimbine hydrochloride and $0.003 \mathrm{mg} / \mathrm{kg}$ naloxone hydrochloride $(2.5 \mathrm{~mL} / 100 \mathrm{~kg}$ live-weight of Contran H; Parnell Laboratories NZ Ltd, Auckland, New Zealand). Animals were held in a recovery pen for 1 to $3 \mathrm{~h}$ prior to being returned to pasture with herd-mates.

\section{Slaughter procedure}

All elk stags at 5-year old were slaughtered at the NIAS slaughterhouse using standard procedures of NIAS when they were in the rut (breeding season). Following slaughter, the carcasses were held in chilled storage $\left(4^{\circ} \mathrm{C}\right)$ for a minimum of $24 \mathrm{~h}$ prior to carcass dissection. For analysis, the longissimus muscle (LM) was excised from the saddle (strip loin or rib eye) at the time of boning. All extraneous fat was manually removed from the loin muscles by a knife. Samples were vacuum packed, and held at $1^{\circ} \mathrm{C}$ to $2^{\circ} \mathrm{C}$ until 7 days post mortem when they were frozen and stored at $-20^{\circ} \mathrm{C}$ until thawed for making quality-related and analytical measurements within 3 months. Samples for assessment were thawed at $1^{\circ} \mathrm{C}$ to $2^{\circ} \mathrm{C}$ overnight and quality characteristics and composition were measured.

\section{Proximate composition and physico-chemical analysis}

All determinations were carried out on the homogenized sample, in triplicate. The proximate composition was determined on samples using a slightly modified method of AOAC (AOAC, 2000). The $\mathrm{pH}$ of samples was determined with a pH meter (PHM 201, Radiometer, Villeurbanne, France). The $\mathrm{pH}$ values of samples were measured by blending a $10 \mathrm{~g}$ sample with $90 \mathrm{~mL}$ distilled water for $60 \mathrm{~s}$ in a homogenizer (Ultra-turrax, T25-S1, Staufen, Germany). The water holding capacity (WHC) was conducted by a modification of the procedure of Kristensen and Purslow (2001). Briefly, a $300 \mathrm{mg}$ sample of muscle was placed in a filter-press device and compressed for $2 \mathrm{~min}$. WHC was calculated from duplicate samples as a ratio of the meat film 
area to the total area; hence, a larger value suggests a higher WHC. WHC (\%) was calculated as follows: WHC (\%) = $100-$ (total meat area/meat film area $\times 100$ ). Shear force values were analyzed by the method described by Purchas et al. (2010). Shear values per core were obtained per animal per cooking temperature from $25 \mathrm{~mm}$-thick steaks that had been cooked for $90 \mathrm{~min}$ in a water bath at either $60^{\circ} \mathrm{C}$ or $70^{\circ} \mathrm{C}$. The samples were prepared a cubic form $(30 \times 30 \times 20 \mathrm{~mm})$ and were cut perpendicular to the longitudinal orientation of the muscle fiber using a square blade with cores having a cross-section across the fibres of $30 \times 30 \mathrm{~mm}$ using a Warner-Bratzler shear attachment on a texture analyzer (TA-XT2, Stable Micro System Ltd., Godalming, UK). The maximum shear force value (kg) was recorded for each sample. Test and post-test speeds were set at $1.0 \mathrm{~mm} / \mathrm{s}$. For cooking loss, after the samples were thawed at $4{ }^{\circ} \mathrm{C}$ overnight before analyses and sliced with a thickness of $2 \mathrm{~cm}$. The samples were weighed and cooked in an electric grill (EMG-533, AIJIA electric appliance, Hong Kong, China) until they reached a final internal temperature of $70^{\circ} \mathrm{C}$. Cooking loss was determined by the ratio of the difference between raw weight and final cooked weight as follows: Cooking loss $(\%)=100 \times$ (raw weight final cooked weight)/raw weight. Color measurements were taken with a Minolta chromameter (Model CR-410, Minolta Co. Ltd., Tokyo, Japan). Commission Internationale de l'Eclairage $\mathrm{L}^{*}, \mathrm{a}^{*}$ and $\mathrm{b}^{*}$ values were determined with measurements standardized with respect to a white calibration plate $\left(\mathrm{L}^{*}=94.4, \mathrm{a}^{*}=0.313, \mathrm{~b}^{*}=0.319\right)$ after 30 min blooming at room temperature. Color measurements for each of three replicates, always trying to avoid area with excess fat, were taken and the value was recorded.

\section{Fatty acid analysis}

Total fat for fatty acid analysis was extracted according to the method of Folch et al. (1957). After thawing the samples, the lipids in a $5 \mathrm{~g}$ sample were extracted in chloroform/methanol (2:1), with $10 \%$ dibutyl hydroxy toluene as an antioxidant. The fatty acid methyl esters (FAMEs) were formed using a $\mathrm{KOH}$ solution in methanol and extracted with water and hexane. The top hexane layer containing FAME was dehydrated through anhydrous $\mathrm{Na}_{2} \mathrm{SO}_{4}$. The extracted and dehydrated hexane was transferred to a vial to be analyzed. Separation and quantification of the fatty acid methyl esters was carried out using a gas chromatograph (GC, Agilent 7890N, Agilent Technologies Seoul, S.L., Seoul, Korea) equipped with a flame ionization detector, automatic sample injector HP 7693, and DB-WAX fused silica capillary column $(30 \mathrm{~m}$, $0.25 \mathrm{~mm}$ i.d., $0.2 \mathrm{~m}$ film thickness, Agilent Technologies Seoul, S.L., Korea). Helium was used as carrier gas at linear flow of $1 \mathrm{~mL} / \mathrm{min}$ and the injection volume was $1 \mathrm{~mL}$. The oven temperature was initially held at $180^{\circ} \mathrm{C}$ for $1 \mathrm{~min}$ then increased at $2.5^{\circ} \mathrm{C} / \mathrm{min}$ to $230^{\circ} \mathrm{C}$ and held for $12 \mathrm{~min}$. The injector (split mode) and detector temperatures were maintained at $280^{\circ} \mathrm{C}$. Linoleic acid (C18:2) was used as an internal standard (catalog number H3500, Sigma-Aldrich Inc. 595 North Harrison Road, Bellefonte, PA 16823-0048, USA). The FAMEs in the total lipids were identified by comparison of the retention times with those of a standard FAME mixture (SuplecoTM 37 Component FAME Mix, Catalog number 47885-UP, Lot number, LB-85684. SigmaAldrich Inc., USA). Fatty acids were expressed as a percentage of total fatty acids identified, saturated fatty acid (SFA), mono-unsaturated fatty acid (MUFA) and polyunsaturated fatty acid (PUFA). PUFA/SFA ratios were calculated.

\section{Cholesterol determination}

Cholesterol concentration was determined by a modification of the procedure of King et al. (1998). For the analysis of cholesterol, $10 \mathrm{~mL}$ of saponification reagent $(33 \% \mathrm{KOH} / \mathrm{ethanol}(\mathrm{w} / \mathrm{v}), 6: 94)$ were added to the lipid extract. The sample was homogenized and then incubated at $50^{\circ} \mathrm{C}$ for $1 \mathrm{~h}$. After cooling, $5 \mathrm{~mL}$ of distilled water and 5 $\mathrm{mL}$ of hexane were added. The contents were mixed thoroughly and the hexane layer containing unsaponifiable matters was dried using nitrogen gas $(99.99 \%)$. The dried sample was then mixed with $200 \mu \mathrm{L}$ of pyridine and $100 \mu \mathrm{L}$ of Sylon bis (trimethylsilyl) trifluoroacetamide $(99 \%$ bistrifluoroacetamide $+1 \%$ trimethylchlorosilane and derivatized at $50^{\circ} \mathrm{C}$ for $1 \mathrm{~h}$. Analysis was performed with a gas chromatograph (HP 6890, Rolla Biotech, Anaheim, CA, USA) equipped with an on-column capillary injector and a flame ionization detector detector. A capillary column (HP5, $30 \mathrm{~m} \times 0.25 \mathrm{~mm} \times 0.25 \mu \mathrm{m})$ and a ramped oven temperature were used (increased to $260^{\circ} \mathrm{C}$ from $180^{\circ} \mathrm{C}$ at $8^{\circ} \mathrm{C} / \mathrm{min}$, then increased to $280^{\circ} \mathrm{C}$ at $2^{\circ} \mathrm{C} / \mathrm{min}$ ). The amounts were calculated using an internal standard, $5 \alpha$-cholestane.

\section{Amino acid analysis}

The composition of free amino acids was determined by the modified method of Hughes et al. (2002). Visible external fat was removed and meat sample $(5 \mathrm{~g})$ was mixed with $20 \mathrm{~mL}$ of $2 \%$ trichloroacetic acid solution. The mixture was homogenized at $13,500 \mathrm{rpm} / \mathrm{min}$ for $1 \mathrm{~min}$. The homogenate was then centrifuged at $17,000 \mathrm{~g}$ for $15 \mathrm{~min}$ and filtered through $0.45 \mu \mathrm{m}$ membrane filter. The filtrate was derivatized by the method of Waters AccQ-TagTM (1993, Millipore Co-Operative, Milford, MA, USA) and 5 $\mu \mathrm{L}$ was injected into an high performance liquid chromatography (HPLC) (Waters HPLC column, Novapak C18. 60 Angstrom, $4 \times 3.9 \times 150 \mathrm{~mm})$. Separation was by using buffers: A (sodium acetate, $\mathrm{pH}$ 6.4, 5,000 ppm ethylenediaminetetraacetic acid (EDTA), triethylamine $(1: 2,000)$ and $6 \%, \mathrm{v} / \mathrm{v}$, acetonitrile) and $\mathrm{B}(60 \%, \mathrm{v} / \mathrm{v}$, 
acetonitrile and 5,000 ppm EDTA). A 1525 HPLC with a binary gradient delivery, a 717 autosampler and an injector, 1500 column heater and 2487 dual wavelength UV detector were the equipment used in the analysis by Breeze software $\mathrm{Z}$ (Waters, USA). Accuracy and repeatability of this analysis is ensured by the inclusion of a control sample of known amino acid composition with the samples prior to hydrolysis.

\section{Statistical methods}

An analysis of variance were performed on all the variables measured using the general linear model procedure of the SAS statistical package (SAS Inst., 2012). T-test $(\mathrm{p}<0.05)$ was used to determine differences between control and the treatment. Mean values and standard deviations were reported.

\section{RESULTS AND DISCUSSION}

\section{Physicochemical characteristics}

Physicochemical characteristics of entire and castrate elk are presented in Table 2. An analysis of the proximate composition of elk (Table 2) showed that the muscle of entire elk had higher content of moisture and lower content of fat than those of the castrates group $(p<0.05)$. Similar result reported that castration increased the fat content of the muscle, yet decreased water content (Tan and Fennessy, 1981). There were no significant differences in crude protein and ash contents between entire and castrate elks. Moisture, crude protein and fat contents were in the range of $73 \%$ to $75 \%, 22 \%$, and $1 \%$ to $2 \%$, respectively. The above finding is consistent with Kim et al. (2006), who found that the moisture, protein and fat content of elk ( $M$.

Table 2. Physicochemical characteristics of entire and castrate elk muscle

\begin{tabular}{lcc}
\hline & Entire & Castrate \\
\hline Chemical composition & & \\
Moisture (\%) & $75.70 \pm 0.13^{\mathrm{a}}$ & $73.50 \pm 0.67^{\mathrm{b}}$ \\
Crude fat (\%) & $1.09 \pm 0.33^{\mathrm{b}}$ & $2.40 \pm 0.58^{\mathrm{a}}$ \\
Crude protein (\%) & $22.00 \pm 0.30$ & $22.40 \pm 0.61$ \\
Crude ash (\%) & $0.92 \pm 0.06$ & $0.88 \pm 0.05$ \\
Physical properties & & \\
pH & $6.15 \pm 0.07^{\mathrm{a}}$ & $5.66 \pm 0.08^{\mathrm{b}}$ \\
WHC & $59.00 \pm 5.09$ & $55.90 \pm 4.33$ \\
Shear force (kg/cm $\left.{ }^{2}\right)$ & $6.80 \pm 0.44^{\mathrm{a}}$ & $3.78 \pm 0.88^{\mathrm{b}}$ \\
Cooking loss & $29.80 \pm 1.81$ & $29.10 \pm 1.49$ \\
$\mathrm{~L}^{* 1}$ & $25.90 \pm 1.02^{\mathrm{b}}$ & $28.20 \pm 1.01^{\mathrm{a}}$ \\
$\mathrm{a}^{* 1}$ & $11.60 \pm 2.08^{\mathrm{b}}$ & $14.50 \pm 0.90^{\mathrm{a}}$ \\
$\mathrm{b}^{* 1}$ & $3.15 \pm 0.93^{\mathrm{b}}$ & $4.77 \pm 0.48^{\mathrm{a}}$ \\
\hline
\end{tabular}

WHC, water holding capacity; SD, standard deviation.

${ }^{1} \mathrm{~L}^{*}$, lightness; $\mathrm{a}^{*}$, redness; $\mathrm{b}^{*}$, yellowness

Data are expressed as means \pm SD $(n=6)$.

${ }^{\mathrm{ab}}$ Different letters in the same row indicate statistical difference $(\mathrm{p}<0.05)$. longissimus dorsi) was $73.1 \%, 22.4 \%$, and $2.11 \%$, respectively. In a study by Dzierzynska-Cybulko and Fruzinski (1997), the protein and fat content of roe deer meat may range from $19.2 \%$ to $24 \%$ and from $0.3 \%$ to $3.7 \%$, respectively. As demonstrated by Paulsen et al. (2005), the average levels of protein and fat in roe deer meat ranged from $20.4 \%$ to $22.2 \%$ and from $0.4 \%$ to $1.6 \%$, respectively. According to Hoffman and Wiklund (2006), venison could fulfill the expectations and dietary requirements of the modern consumer, due to a low content of fat with a desirable fatty acid composition, and high levels of protein. In our study, the high protein content and the low fat content in the Korean elk meat obtained indicating a similar result compared to the previous findings.

As shown in Table 2, the $\mathrm{pH}$ and shear force values of the muscles were lower in castrates group than in entire group $(\mathrm{p}<0.05)$. In this study, the average $\mathrm{pH}$ of meat from entire and castrate was 6.15 and 5.66, respectively. The differences in the $\mathrm{pH}$ of the meat of both entire and castrate may be attributed to pre-slaughter stress factors and the animals' reproductive cycle (Wiklund et al., 1996). Stags in the period of the rut (breeding season) should be more aggressive than when not in rut. It is vital to relieve stressors during transportation and holding period for stags.

The difference in shear force has been shown to be associated with the connective tissue contribution to meat toughness (Beilken et al., 1986), and this was higher for the entire elk. Basically, wild venison is regarded to have a darker color than the meat of domesticated animals (Hoffman and Wiklund, 2006). This dark color may be caused by the animals being stressed during hunting. Another probable explanation excluding that due to stress is that wild animals are more active with aggressive behavior during the rut and tend to run more than the traditionally farmed animals such as cattle and sheep (Daszkiewicz et al., 2012). The color $L^{*}, a^{*}$, and $b^{*}$ values of muscles were higher in castrate than the entires $(\mathrm{p}<0.05)$. Similar result has found that entire males compared with castrates produce darker meat (Seideman et al., 1982). The darker color of elk meat is due to its higher $\mathrm{pH}$, as a result of higher rates of ante-mortem glycolysis (Wiklund et al., 1996). In relation to WHC, determined either by drip or cooking losses, the differences meat of entire and castrate elks did not differ significantly with respect to cooking loss and WHC (Table 2 ). WHC is an important meat quality attribute as loss of water in the form of purge or drip affects the appearance of vacuum packaged meat and is also related to the juiciness of cooked meat for table purposes (Wiklund et al., 2003). Available data regarding the effect of castration on the WHC of elk meat are inconclusive.

\section{Fatty acid composition and cholesterol}

Fatty acid composition and cholesterol of entire and castrate elk are shown in Table 3. In our study, the 
predominant saturated fatty acids in elk meat were palmitic acid (C16:0) and stearic acid (C18:0), the predominant MUFA was oleic acid (C18:1), and the predominant polyunsaturated fatty acid was linoleic acid (C18:2). These results are consistent with those from other studies with deer (Wiklund et al., 2003; Purchas et al., 2010; Daszkiewicz et al., 2012). Levels of oleic acid (generally considered a "good" fatty acid with respect to human health) in beef are usually greater than $30 \%$ of total fatty acid (Purchas et al., 2010). The elk contains lower proportions of oleic acid (26.5\% to $26.8 \%)$ than beef in this study. This may be a reflection of the very low level of intramuscular fat in venison, as the proportion of this oleic acid usually increases as fat levels increase within meat (Purchas et al., 2010).

There were significant effects of castration on the fatty acid composition of elk only in some unsaturated fatty acid (UFA). Table 3 shows that linolenic acid (C18:3n6), eicosenoic acid (C20:1n9), and arachidonic acid (C20:4n6) were present at a higher concentration in the entire group $(p<0.05)$. These differences are likely to be due to the strong tendency for concentrations of polyunsaturated fatty acids to be higher when total fat levels are lower (Wood et al., 2008), as entire elk had lower content of fat than castrates in our study. Dryden (1997) demonstrated that castration reduced the proportion of linolenic acid and a similar result was reported in the present study. The PUFA/SFA $(\mathrm{P} / \mathrm{S})$ ratio is a key indicator of the nutritional value of food products, and its low values contribute to the

Table 3. Fatty acid composition and cholesterol content of entire and castrate elk muscle

\begin{tabular}{|c|c|c|}
\hline & $\begin{array}{c}\text { Entire } \\
(\mathrm{mg} / 100 \mathrm{~g})\end{array}$ & Castrate \\
\hline Myristic acid (C14:0) & $6.58 \pm 0.90$ & $6.38 \pm 0.57$ \\
\hline Palmitic acid (C16:0) & $29.90 \pm 0.11$ & $32.00 \pm 1.54$ \\
\hline Palmitoleic acid (C16:In7) & $6.25 \pm 1.10$ & $7.87 \pm 1.32$ \\
\hline Stearic acid (C18:0) & $23.20 \pm 1.42$ & $20.30 \pm 2.83$ \\
\hline Oleic acid (C18:In9) & $26.50 \pm 1.60$ & $26.80 \pm 1.28$ \\
\hline Linoleic acid (C18:2n6) & $5.58 \pm 0.30$ & $5.28 \pm 0.35$ \\
\hline$\gamma$-Linolenic acid (C18:3n6) & $0.18 \pm 0.02^{\mathrm{a}}$ & $0.14 \pm 0.02^{\mathrm{b}}$ \\
\hline Linolenic acid (C18:3n3) & $0.32 \pm 0.11$ & $0.37 \pm 0.07$ \\
\hline Eicosenoic acid (C20:1n9) & $0.44 \pm 0.02^{\mathrm{a}}$ & $0.36 \pm 0.03^{b}$ \\
\hline Arachidonic acid (C20:4n6) & $1.05 \pm 0.05^{\mathrm{a}}$ & $0.65 \pm 0.09^{b}$ \\
\hline $\mathrm{SFA}^{2)}$ & $59.70 \pm 2.21$ & $58.60 \pm 1.96$ \\
\hline $\mathrm{UFA}^{2)}$ & $40.30 \pm 2.21$ & $41.40 \pm 1.96$ \\
\hline MUFA $^{2)}$ & $33.20 \pm 2.73$ & $35.00 \pm 1.84$ \\
\hline PUFA $^{2)}$ & $7.12 \pm 0.52$ & $6.43 \pm 0.46$ \\
\hline PUFA /SFA ${ }^{2)}$ & 0.12 & 0.11 \\
\hline Cholesterol (mg/100 g muscle) & $40.10 \pm 6.36$ & $38.70 \pm 2.52$ \\
\hline \multicolumn{3}{|c|}{$\begin{array}{l}\text { SFA, saturated fatty acids; UFA, unsaturated fatty acids; MUFA } \\
\text { monounsaturated fatty acids; PUFA, polyunsaturated fatty acids; SD } \\
\text { standard deviation. } \\
\text { Data are expressed as means } \pm \mathrm{SD}(\mathrm{n}=6) \\
\text { ab } \text { Different letters in the same row indicate statistical difference }(\mathrm{p}<0.05) \text {. }\end{array}$} \\
\hline
\end{tabular}

development of cardiovascular diseases (Daszkiewicz et al., 2012). According to Wood et al. (2008), the normal P/S ratio in ruminant meat is around 0.1 because dietary unsaturated fatty acids are hydrogenated by rumen microorganisms. Similarly, the $\mathrm{P} / \mathrm{S}$ ratio was in the range of $0.11 \%$ to $0.12 \%$. The result showed that cholesterol content in longissimus muscles of entires had higher than those of castrates, even though they were not significantly different. Cholesterol content in LD muscles of entire and castrate elk were 40.1 and $38.7 \mathrm{mg} / 100 \mathrm{~g}$, respectively. Drew et al. (1991) recorded that the cholesterol content of loin muscles of red deer was $66 \mathrm{mg} / 100 \mathrm{~g}$.

\section{Free amino acid composition}

The profile of free amino acids of a food is known to be related to the development of a particular taste, flavor or aroma like saltiness, acid taste, bitter taste, etc. (Lim et al., 2014). Taste is classified into four categories of amino acid: saccharinity (threonine, serine, glycine, and alanine), amino acid with sulfide (methionine, cystine), fragrant amino acid (phenylalanine, tyrosine), and essential amino acid (threonine, valine, methionine, isoleucine, leucine, phenylalanine, histidine, lysine, and arginine) (Lim et al., 2014). The free amino acid composition of entire and castrate elk is given in Table 4. The predominant free amino acid for the present study was glutamic acid related to umami taste. Castrate group had higher percentage of Histidine, isoleucine, and leucine than those of entire group $(p<0.05)$. There were few published data on the effect of

Table 4. Free amino acid composition (\%) of entire and castrate elk muscle

\begin{tabular}{lcc}
\hline & $\begin{array}{c}\text { Entire } \\
(\mathrm{mg} / 100 \mathrm{~g} \text { muscle })\end{array}$ & Castrate \\
\hline Ala & $1.19 \pm 0.04$ & $1.24 \pm 0.03$ \\
Arg & $1.32 \pm 0.03$ & $1.34 \pm 0.03$ \\
Asp & $1.90 \pm 0.05$ & $1.97 \pm 0.06$ \\
Cys & $0.24 \pm 0.01$ & $0.25 \pm 0.01$ \\
Glu & $3.39 \pm 0.14$ & $3.33 \pm 0.07$ \\
Gly & $0.88 \pm 0.07$ & $0.93 \pm 0.03$ \\
His & $0.65 \pm 0.01^{\mathrm{b}}$ & $0.74 \pm 0.08^{\mathrm{a}}$ \\
Ile & $0.88 \pm 0.01^{\mathrm{b}}$ & $0.91 \pm 0.02^{\mathrm{a}}$ \\
Leu & $1.75 \pm 0.03^{\mathrm{b}}$ & $1.82 \pm 0.02^{\mathrm{a}}$ \\
Lys & $1.88 \pm 0.04$ & $1.93 \pm 0.05$ \\
Met & $0.55 \pm 0.01$ & $0.58 \pm 0.02$ \\
Phe & $0.84 \pm 0.03$ & $0.87 \pm 0.03$ \\
Pro & $0.77 \pm 0.04$ & $0.79 \pm 0.03$ \\
Ser & $0.83 \pm 0.05$ & $0.86 \pm 0.03$ \\
Thr & $0.95 \pm 0.02$ & $0.97 \pm 0.04$ \\
Tyr & $0.65 \pm 0.01$ & $0.67 \pm 0.02$ \\
Val & $1.00 \pm 0.03$ & $1.02 \pm 0.04$ \\
\hline
\end{tabular}

SD, standard deviation.

Data are expressed as means $\pm \operatorname{SD}(n=6)$.

${ }^{\text {ab }}$ Different letters in the same row indicate statistical difference $(\mathrm{p}<0.05)$. 
castration in venison from elk and this is an area which needs further clarification.

\section{CONCLUSION}

This study has revealed several differences in quality traits, as well as fatty acid and amino acid composition characteristics between venison from entire and castrate elk. It was concluded that castration could affect the physicochemical composition. These results show that castration affected the chemical composition of the meat, inducing a decrease in water and an increase in fat contents in castrated animals. The result showed that the dominant SFA was palmitic acid (C16:0) and stearic (C18:0), and oleic acid (C18:1n-9) is the highest UFA in muscles of both elk. The concentrations of some UFA were higher in meat from entire elk, probably due to a lower fat content. Further research, on a larger number of animals, is required before definite conclusions can be made on the usefulness of castration to improve the meat production in elk.

\section{CONFLICT OF INTEREST}

We certify that there is no conflict of interest with any financial organization regarding the material discussed in the manuscript.

\section{ACKNOWLEDGMENTS}

This study was carried out with the support of "cooperative research program (protein requirement for growing stage of goat and deer, No. PJ00943001)", Rural Development Administration, Republic of Korea.

\section{REFERENCES}

AOAC. 2000. Official Methods of Analysis. 17th edn. Association of Official Analytical Chemists. Arlington, VA, USA.

Asher, G. W., J. A. Archer, J. F. Ward, C. G. Mackintosh, and R. P. Littlejohn. 2011. The effect of prepubertal castration of red deer and wapiti-red deer crossbred stags on growth and carcass production. Livest. Sci. 137:196-204.

Beilken, S. L., P. E. Bouton, and P. V. Harris. 1986. Some effects on the mechanical properties of meat produced by cooking at temperatures between $50^{\circ} \mathrm{C}$ and $60^{\circ} \mathrm{C}$. J. Food Sci. 51:791-796.

Daszkiewicz, T., D. Kubiak, R. Winarski, and M. KobaKowalczyk. 2012. The effect of gender on the quality of roe deer (Capreolus capreolus L.) meat. Small Rumin. Res. 103:169-175

Drew, K. R., J. M. Stevenson, and P. F. Fennessey. 1991. Venisona marketable product. In: Proceedings of a Deer Course for Veterinarians No. 8. Deer Branch of New Zealand Veterinary Association, Massey Univ., Palmerston North, New Zealand. pp. 31-35.

Dryden, G. M. 1997. Venison in the human diet- is venison a low- fat meat? Proceedings of the Nutrition Society of Australia. 21:44-51

Dzierzynska-Cybulko, B. and B. Fruzinski. 1997. Game as a source of food. PWRiL, Poznan, Poland.

Folch, J., M. Lees, and G. H. Sloane-Stanley. 1957. A simple method for the isolation and purification of total lipids from animal tissues. J. Biol. Chem. 226:497-507.

Hoffman, L. C. and E. Wiklund. 2006. Game and venison meat for the modern consumer. Meat Sci. 74:197-208.

Hughes, M. C., J. P. Kerryb, E. K. Arendtb, P. M. Kenneallyc, P. L. H. McSweeneya, and E. E. O'Neilla. 2002. Characterization of proteolysis during the ripening of semi-dry fermented sausages. Meat Sci. 62:205-216.

Kim, I. S., S. K. Jin, K. H. Hah, S. T. Park, K. R. Kwak, J. K. Park, and Y. S. Kang. 2006. Physico-Chemical, Fatty Acid Composition and Sensory Properties of Venison from Cervus elaphus andadensis (Elk Deer). Korean J. Food Sci. Anim. Resour. 26:70-77.

King, A. J., P. Paniangvait, A. D. Jones, and J. B. German. 1998. Rapid method for quantification of cholesterol in turkey meat and products. J. Food Sci. 63:382-385.

Kristensen, L. and P. P. Purslow. 2001. The effect of ageing on the water-holding capacity of pork: role of cytoskeletal proteins. Meat Sci. 58:17-23.

Li, C. 2003. Development of deer antler model for biomedical research. Recent Adv. Res. Updat. 4:255-274.

Lim, D. G., C. Jo, K. S. Seo, and K. C. Nam. 2014. Comparison of meat quality of loins and butts in different two-way crossbred pigs. Livest. Sci. 161:210-217.

Miao, Z. H., P. C. Glatz, A. English, and Y. J. Ru. 2001. Managing fallow deer and red deer for animal house research. ANZCCART News 14:1-8.

Ministry of Agriculture, Food and Rural Affairs. 2013. Statistics of farmed deer and number of slaughtered deer in Canada. http://www.omafra.gov.on.ca/english/stats/livestock/redmeat.html Accessed December 30, 2013.

Paulsen, P., F. Bajer, R. Winkelmayer, F. J. M. Smulders, and P. Hofbauer. 2005. A note on quality traits of vacuum packaged meat from roe-deer cut and deboned 12 and $24 \mathrm{~h}$ post mortem. Fleischwirtschaft 11:114-117.

Pearse A. J. and L. Fung. 2007. The Deer Industry's Productivity Strategy: A five-year vision. In: Proceedings of the NZ Society Animal Production. New Zealand Soc. Anim. Prod. 67:73-77.

Pitra, C., J. Fickel, E. Meijaard, and C. Groves. 2004. Evolution and phylogeny of old world deer. Mol. Phylogenet. Evol. 33:880-895.

Purchas, R. W., E. C. Triumf, and B. Egelandsdal. 2010. Quality characteristics and composition of the longissimus muscle in the short-loin from male and female farmed red deer in New Zealand. Meat Sci. 86:505-510.

SAS. 2012. SAS User's Guide, SAS Institute Inc., Cary, NC, USA. Seideman, S. C., H. R. Cross, R. R. Oltjen, and B. D. Schanbacher. 1982. Utilization of the intact male for red meat production: A review. J. Anim. Sci. 55:826-840.

Shin, H. T., R. J. Hudson, X. H. Gao, and J. M. Suttie. 2000. Nutritional requirements and management strategies for farmed deer - review -. Asian Australas. J. Anim. Sci. 13:561573

Statistics New Zealand. 2010. Statistics for deer production in 
New Zealand. http://www.stats.govt.nz/agriculture 1 December, Wiklund, E., T. R. Manley, R. P. Littlejohn, and J. M. Stevenson2010.

Tan, G. Y. and P. F. Fennessy. 1981. The effect of castration on some muscles of red deer (Cervus elaphus). NZ J. Agric. Res. 24:1-3.

Wiklund, E., A. Andersson, G. Malmfors, and K. Lundstrom. 1996. Muscle glycogen levels and blood metabolites in reindeer (Rangifer Tarandus Tarandus L.) after transport and lairage. Meat Sci. 42:133-144. Barry. 2003. Fatty acid composition and sensory quality of musculus longissimus and carcass parameters in red deer (Cervus elaphus) grazed on natural pasture or fed a commercial feed mixture. J. Sci. Food Agric. 83:419-424.

Wood, J. D., M. Enser, A. V. Fisher, G. R. Nute, P. R. Sheard, R. I. Richardson, S. I. Hughes, and F. M. Whittington. 2008. Fat deposition, fatty acid composition and meat quality: A review. Meat Sci. 78:343-358. 